\title{
PERAN ANTIOKSIDAN DALAM MENGATASI CEKAMAN KEKERINGAN PADA TANAMAN KEDELAI (Glycine max (L.) Merril)
}

\author{
Laily Asyura AG \\ Program Studi Agroteknologi \\ Fakultas Pertanian, Universitas Sumatera Utara, Medan 20155, Indonesia \\ lailyasyura43@gmail.com
}

\begin{abstract}
The decreasing of soybean production full fill of soybean in Indonesia, one of the main causes is the decreasing of land farming area. To increase the production of soybean in Indonesia can be reached by the expansion of planting areas, use potential land. This research has held in plastic house Agriculture Faculty, University of Sumatera Utara, Medan on altitude +32 meters above sea level, to August 2016 until November 2016, using factorial rendomized block design with 2 factors. The first factor is drought stress with 3 levelsof KL 80\%; KL 60\%; KL 40\% and the second factor is apllication antioxidants with 2 kind of Ascorbic Acid and Salicylic Acid.The result of this research showed that drought stresswere significantly effect to leaf area, the number of pods fullness per plant, dry weight of seeds per plant and dry weight of 100 seeds. Apllication antioxidantswere significantly effect to chlorophyll a, chlorophyll $b$, thenumber of pods fullness per plant, dry weight of seeds per plant and dry weight of 100 seeds.Interaction of drought stress and application antioxidant were significantly effect to dry weight of seeds per plant and dry weight of 100 seeds.
\end{abstract}

Abstrak
Produksi kedelai yang semakin menurun tidak dapat memenuhi kebutuhan kedelai di Indonesia, salah satu penyebab utamanya yaitu semakin sempitnya lahan pertanian. Untuk meningkatkan produksi kedelai di Indonesia dapat ditempuh dengan cara perluasan areal tanam, yaitu dengan memanfaatkan tanah yang berpotensi. Penelitian ini dilaksanakan di rumah plastik Fakultas Pertanian Universitas Sumatera Utara, Medan dengan ketinggian tempat +32 meter di atas permukaan laut dari bulan Agustus 2016 sampai November 2016, menggunakan rancangan acak kelompok dengan 2 faktor perlakuan. Faktor pertama adalah cekaman kekeringan dengan 3 taraf yaitu KL 80\% ; KL 60\% ; KL 40\% dan faktor kedua adalah pemberian antioksidan dengan 2 macam yaitu asam salisilat dan asam askorbat. Hasil penelitian menunjukkan bahwa perlakuan cekaman kekeringan berpengaruh nyata terhadap parameter total luas daun, polong berisi pertanaman, bobot kering biji pertanaman, dan bobot kering 100 biji. Perlakuan pemberian antioksidan berpengaruh nyata terhadap par meter klorofil daun a, klorofil daun b,jumlah polong berisi per tanaman,bobot kering biji per tanaman, dan bobot kering 100 biji. Interaksi perlakuan cekaman kekeringan dan antioksidan berpengaruh nyata terhadap parameter bobot kering biji per tanaman dan bobot kering biji per tanaman.

Kata kunci: Kedelai, cekaman kekeringan, antioksidan 


\section{Pendahuluan}

Kedelai merupakan salah satu komoditas tanaman pangan yang bernilai ekonomis penting, karena perannya sebagai pemenuhan kebutuhan gizi yang terjangkau masyarakat luas.Selain itu, kedelai juga merupakan sumber protein nabati dengan kandungan 39\%, di mana $2 \%$ dari seluruh rakyat Indonesia memperoleh sumber protein dari kedelai. Dilihat dari segi pangan dan gizi, kedelai merupakan sumber protein yang paling murah di dunia. Kedelai sebagai bahan baku makanan yang banyak dikonsumsi rakyat Indonesia yaitu tempe dan tahu (Ramadhani, 2009).

Lahan kering merupakan hamparan lahan yang tidak pernah digenangi atau tergenang air pada sebagian besar waktu dalam setahun.Lahan kering ini terjadi sebagai akibat dari curah hujan yang sangat rendah, sehingga keberadaan air sangat terbatas, suhu udara tinggi dan kelembabannya rendah. Lahan kering ditandai dengan rendahnya curah hujan $(<250-300$ $\mathrm{mm} /$ tahun), indek kekeringan (rasio / perbandingan antara curah hujan dan evapotranspirasi kurang dari 0.2), variasi tanaman sangat terbatas (hanya semak belukar, rerumputan dan pepohonan kecil di daerah tertentu), suhu yang sangat tinggi $\left( \pm 49^{\circ} \mathrm{C}\right.$ pada musim panas), tekstur tanah adalah pasir dan memiliki salinasi yang tinggi pada tanah dan air tanahnya yang diakibatkan oleh tingginya evaporasi dan infiltrasi (Notohadinegoro, 2000).

Kekeringan sangat mempengaruhi pertumbuhan dan pengembangan tanaman.Serta penurunan produksi karena kekeringan yaitu mempengaruhi pengisian biji dan akumulasi biomassa, konsekuensi utama kekeringan pada tanaman yang tingkat pembelahan sel, pengurangan ukuran daun, dan terganggunya regulasi stomata, produkstivitas tanaman berkurang, dan efisiensi penggunaan air.Salah satu cara untuk mengatasi kondisi cekaman kekeringan yaitu dengan pemerian antioksidan (Li ,et al., 2014).

Senyawa antioksidan adalah senyawa yang mampu menangkal atau meredam dampak negatif oksidan dalam tubuh. Antioksidan bekerja dengan cara menyumbangkan satu atau lebih elektron kepada radikal bebas,sehingga radikal bebas tersebut dapat diredam (Fentami, 2012).

Antioksidan berfungsi membantu melindungi tubuh dari serangan radikal bebas serta meredan dampak negatifnya. Antioksidan merupakan komponen yang dapat melindungi sel dari kerusakan yang diakibatkan oleh reaktif oksigen spesies seperti oksigen singlet, superoksida, radikal hidroksil, radikal peroksil, dan peroksi nitrit. Radikal bebas sebetulnya sangat diperlukan bagi kelangsungan beberapa proses fisiologi dalam tubuh, terutama untuk transportasi elektron. Namun radikal bebas yang berlebihan dapat membahayakan tubuh karena dapat merusak makromolekul dalam sel seperti protein dan DNA (deoxyribo nucleic acid). Kerusakan makromolekul selanjutnya dapat mengakibatkan kematian sel (Julyasih et al, 2009).

Kemampuan antioksidan untuk menginduksi toleransi cekaman terhadap cekaman abiotik tergantung dari jenis tanaman, tahap perkembangan, metode aplikasi dan konsentrasi antioksidan.Upaya peningkatan kandungan antioksidan dapat dilakukan dengan aplikasi 
antioksidan eksogenous.Beberapa jenis antioksidan yang dapat digunakan adalah asam askorbat dan asam salisilat (Ardiansyah, 2013; Salehi et al, 2011; Lamid, 1995).

Salah satu upaya untuk meningkatkan toleransi terhadap stres oksidatif adalah dengan aplikasi asam askorbat (vitamin C). Asam askorbat adalah molekul yang berukuran kecil, larut dalam air, merupakan antioksidan yang bertindak sebagai substrat utama dalam jalur siklik detoksifikasi enzimatik hidrogen peroksida.Asam askorbat adalah zat pertama dalam detoksifikasi dan menetralkan radikal superoksida. Asam askorbat juga berperan penting dalam fotoproteksi, regulasi fotosintesis, serta proses pertumbuhan tanaman seperti pembelahan sel dan ekspansi dinding sel (Ardiansyah, 2013).

Asam salisilat memegang peranan penting dalam ketahanan sistemik terinduksi.Mekanisme ketahanan tanaman terhadap penyakit dapat berupa ketahanan secara fisik maupun kimia.Salah satu bentuk ketahanan secara kimia adalah asam salisilat.Asam salisilat lebih dominan untuk mengatasi serangan patogen biotrof (patogen yang aktif pada jaringan hidup) dan virus.Mekanisme ketahanan melalui jalur asam salisilat berhubungan dengan proteinprotein yang terkait dengan patogenesis (Sulastri, 2014).

Li et al. (2014) menyatakan bahwa peningkatan toleransi tanaman terhadap cekaman kekeringan dengan aplikasi asam salisilat eksogenous tergantung dari genotipa tanaman dan konsentrasi asam salisilat yang digunakan sehingga perlu penjelasan lebih lanjut mengenai hal tersebut.

\section{Bahan dan Metode}

Penelitian dilaksanakan di rumah kasa Fakultas Pertanian Universitas Sumatera Utara, Medan dengan ketinggian tempat \pm 32 meter di atas permukaan laut, pada bulan Agustus November 2016.

Bahan yang digunakan ialah benih kedelai varietas Wilis sebagai objek yang akan diamati, antioksidan (asam salisilat dan asam askorbat) sebagai perlakuan yang akan diaplikasikan pada tanaman kedelai, polibeg untuk wadah media tanam, air untuk menyiram tanaman dan bahan-bahan lain yang mendukung penelitian ini.

Alat yang digunakan yaitu cangkul untuk membersihkan gulma pada rumah plastik, pisau/cutter untuk memotong-motong plastik, label sebagai penanda,meteran untuk mengukur, sprayer untuk mengaplikasikan antioksidan, timbangan analitik untuk menimbang bobot yang akan ditimbang, gembor untuk menyiram, serta alat pendukung lainnya.

Penelitian menggunakan Rancangan Acak Kelompok faktorial dengan 2 faktor perlakuan yaitu faktor 1 (Cekaman Kekeringan (K) dengan 3 taraf) : K1 : $80 \%$ Kapasitas Lapang $(\mathrm{KL}), \mathrm{K} 2$ : $60 \%$ Kapasitas Lapang (KL),K3 : 40 \% Kapasitas Lapang (KL) dan faktor 2 (Pemberian Antioksidan (A) dengan 3 jenis): A0 : Tanpa Antioksidan (Kontrol), A1 :Asam Salisilat (500 ppm). A2 : Asam Askorbat(500 ppm).

Jika hasil sidik ragam menunjukkan pengaruh yang nyata, maka analisis dilanjutkan dengan menggunakan Uji Jarak Berganda Duncan pada taraf $\alpha=5 \%$ (Steel and Torrie, 1993). 
Parameter yang diamati adalah diameter batang $(\mathrm{cm})$, total luas daun $\left(\mathrm{cm}^{2}\right)$, umur berbunga (hst), kehijauan daun (mg/l), bobot kering tajuk (g), bobot kering tajuk (g),rasio akar tajuk, jumlah cabang produktif, jumlah polong berisi per tanaman (polong), jumlah polong hampa per tanaman (polong), bobot kering biji/plot (g), bobot 100 biji kering.

\section{Hasil dan Pembahasan}

\section{Hasil}

Berdasarkan hasil sidik ragam (Lampiran 5-32) diketahui bahwa pengaruh cekaman kekeringanberpengaruh nyata terhadap total luas daun, jumlah polong berisi pertanaman, bobot kering biji pertanaman, dan bobot kering 100 biji, dan berpengaruh tidak nyata diameter batang, umur berbunga,klorofil a, klorofil b, total klorofil, bobot kering tajuk, bobot kering akar, rasio tajuk akar, jumlah cabang produktif dan jumlah polong hampa per tanaman. Sedangkan pemberian antioksidan berpengaruh nyata terhadap klorofil a, klorofil b,jumlah polong berisi pertanaman, bobot kering biji pertanaman dan bobot kering 100 biji dan berpengaruh tidak nyata terhadap diameter meter, total luas daun, umur berbunga, total klorofil, bobot kering tajuk, bobot kering akar, rasio tajuk akar, jumlah cabang produktif dan jumlah polong hampa per tanaman. Interaksi antara pengaruh cekaman kekeringan dan pemberian antioksidan berpengaruh nyata terhadapbobot kering biji pertanaman, dan bobot kering 100 biji.

\section{Diameter Batang}

Cekaman kekeringan, pemberian antioksidan dan interaksi antara keduanya berpengaruh tidak nyata terhadap diameter batang.

Tabel 1. Diameter batang kedelai dengan perlakuan cekaman kekeringan dan pemberian antioksidan.

\begin{tabular}{|c|c|c|c|c|}
\hline \multirow{2}{*}{$\begin{array}{l}\text { Cekaman } \\
\text { Kekeringan } \\
(\% \mathrm{KL})\end{array}$} & \multicolumn{3}{|c|}{ Antioksidan } & \multirow[b]{2}{*}{ Rataan } \\
\hline & $\begin{array}{c}\text { A0 } \\
\text { (Kontrol) }\end{array}$ & $\begin{array}{c}\text { A1 } \\
\text { (Asam Salisilat) }\end{array}$ & $\begin{array}{c}\text { A2 } \\
\text { (Asam Askorbat) }\end{array}$ & \\
\hline & & ....cm.. & $\ldots \ldots$ & \\
\hline K1 (80) & 3.84 & 3.87 & 4.06 & 3.92 \\
\hline K2 (60) & 3.70 & 3.76 & 3.89 & 3.78 \\
\hline K3 (40) & 3.78 & 3.63 & 3.93 & 3.78 \\
\hline Rataan & 3.77 & 3.75 & 3.96 & \\
\hline
\end{tabular}

\section{Total Luas Daun}

Cekaman kekeringan, pemberian antioksidan dan interaksi antara keduanya berpengaruh tidak nyata terhadap total luas daun. Rataan total luas daun pada perlakuan cekaman kekeringan dan pemberian antioksidan dapat dilihat pada Tabel 2. 
Tabel 2.Total luas daun kedelai dengan perlakuan cekaman kekeringan dan pemberian antioksidan.

\begin{tabular}{|c|c|c|c|c|}
\hline \multirow{3}{*}{$\begin{array}{l}\text { Cekaman } \\
\text { Kekeringan } \\
(\% \mathrm{KL})\end{array}$} & \multicolumn{3}{|c|}{ Antioksidan } & \multirow{3}{*}{ Rataan } \\
\hline & A0 & A1 & A2 & \\
\hline & (Kontrol) & (Asam Salisilat) & (Asam Askorbat) & \\
\hline & \multicolumn{4}{|c|}{ 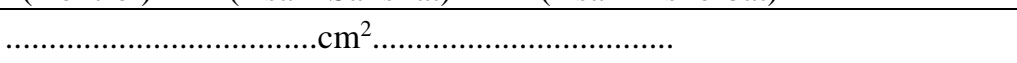 } \\
\hline K1 (80) & 658.67 & 648.76 & 617.34 & $641.59 \mathrm{a}$ \\
\hline K2 (60) & 577.65 & 645.80 & 560.01 & $594.49 \mathrm{a}$ \\
\hline K3 (40) & 485.21 & 507.88 & 438.25 & $477.11 \mathrm{~b}$ \\
\hline Rataan & 573.84 & 600.81 & 538.53 & \\
\hline
\end{tabular}

\section{Umur Berbunga}

Rataan umur berbunga pada perlakuan cekaman kekeringan dan pemberian antioksidan dapat dilihat pada Tabel 3.

Tabel 3. Umur berbunga kedelai dengan perlakuan cekaman kekeringan dan pemberian antioksidan

Cekaman Kekeringan $(\% \mathrm{KL})$

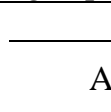

A0 Antioksidan

A1 A2 Rataan

(Kontrol) (Asam Salisilat) (Asam Askorbat)

\begin{tabular}{lllll}
\hline & $\ldots \ldots \ldots \ldots \ldots \ldots \ldots \ldots \ldots \ldots \ldots \ldots \ldots \ldots \ldots \ldots \ldots \ldots \ldots \ldots \ldots \ldots \ldots \ldots \ldots$ & \\
K1 (80) & 38.67 & 39.00 & 38.67 & 38.78 \\
K2 (60) & 39.00 & 38.33 & 39.00 & 38.78 \\
K3 (40) & 38.33 & 38.33 & 39.00 & 38.56 \\
\hline Rataan & 38.67 & 38.56 & 38.89 & \\
\hline
\end{tabular}

\section{Klorofil Daun}

Rataan kandungan klorofil a, klorofil $\mathrm{b}$ dan total klorofil pada perlakuan cekaman kekeringan dan pemberian antioksidan dapat dilihat pada Tabel 4.

Tabel 4. Kandungan Klorofil a, Klorofil b, dan Total Klorofil Daun pada kedelai dengan perlakuan cekaman kekeringan dan pemberian antioksidan.

\begin{tabular}{|c|c|c|c|c|c|}
\hline \multirow{3}{*}{$\begin{array}{l}\text { Peubah } \\
\text { Amatan }\end{array}$} & \multirow{3}{*}{$\begin{array}{l}\text { Cekaman } \\
\text { Kekeringan } \\
(\%)\end{array}$} & \multicolumn{3}{|c|}{ Antioksidan } & \multirow{3}{*}{ Rataan } \\
\hline & & A0 & A1 & $\mathrm{A} 2$ & \\
\hline & & (Kontrol) & Asam Salisilat & Asam Askorbat & \\
\hline \multirow{6}{*}{ Klorofil a } & & $\cdots$ & ........mg/l...... & . & \\
\hline & K1 (80) & 1.70 & 1.85 & 1.82 & 1.79 \\
\hline & K2 (60) & 1.84 & 1.89 & 1.90 & 1.88 \\
\hline & K3 (40) & 1.76 & 2.07 & 1.89 & 1.90 \\
\hline & Rataan & $1.76 \mathrm{~b}$ & $1.94 \mathrm{a}$ & $1.87 \mathrm{ab}$ & \\
\hline & K1 (80) & 2.31 & 1.86 & 1.80 & 1.99 \\
\hline Klorofil b & K2 (60) & 2.19 & 1.76 & 2.07 & 2.01 \\
\hline
\end{tabular}




\begin{tabular}{cccccc} 
& K3 $(40)$ & 2.73 & 1.46 & 2.09 & 2.09 \\
\hline \multirow{2}{*}{ Total } & Rataan & $2.41 \mathrm{~b}$ & $1.69 \mathrm{a}$ & $1.99 \mathrm{ab}$ & \\
Klorofil & K1 (80) & 4.00 & 3.71 & 3.61 & 3.77 \\
& K2 (60) & 3.97 & 3.54 & 3.94 & 3.82 \\
& K3 (40) & 4.49 & 3.25 & 3.97 & 3.90 \\
\hline
\end{tabular}

Keterangan: Angka-angka yang diikuti huruf yang sama menunjukkan berbeda tidak nyata menurut Uji Duncan Multiple Tect pada taraf $\alpha=5 \%$

\section{Bobot Kering Tajuk}

Rataan bobot kering tajuk pada perlakuan cekaman kekeringan dan pemberian antioksidan dapat dilihat pada Tabel 5.

Tabel 5. Bobot Kering Tajuk Kedelai kedelai dengan perlakuan cekaman kekeringan dan pemberian antioksidan.

\begin{tabular}{|c|c|c|c|c|}
\hline \multirow{2}{*}{$\begin{array}{c}\text { Cekaman Kekeringan } \\
(\% \mathrm{KL})\end{array}$} & \multicolumn{3}{|c|}{ Antioksidan } & \multirow[b]{2}{*}{ Rataan } \\
\hline & $\begin{array}{c}\text { A0 } \\
\text { (Kontrol) }\end{array}$ & $\begin{array}{c}\text { A1 } \\
\text { (Asam Salisilat) }\end{array}$ & $\begin{array}{c}\text { A2 } \\
\text { (Asam Askorbat) }\end{array}$ & \\
\hline & $\ldots$. &..$g \ldots \ldots$ & $\ldots$. & \\
\hline K1 (80) & 3.15 & 3.44 & 4.09 & 3.56 \\
\hline K2 (60) & 3.88 & 3.30 & 3.61 & 3.59 \\
\hline K3 (40) & 3.84 & 3.81 & 3.26 & 3.64 \\
\hline Rataan & 3.62 & 3.51 & 3.65 & \\
\hline
\end{tabular}

\section{Bobot Kering Akar}

Rataan bobot kering akar pada perlakuan cekaman kekeringan pemberian antioksidan dapat dilihat pada Tabel 6 .

Tabel 6. Bobot Kering Akar Kedelai kedelai dengan perlakuan cekaman kekeringan dan pemberian antioksidan.

\begin{tabular}{|c|c|c|c|c|}
\hline \multirow{3}{*}{$\begin{array}{c}\text { Cekaman Kekeringan } \\
(\% \mathrm{KL})\end{array}$} & \multicolumn{3}{|c|}{ Antioksidan } & \multirow{3}{*}{ Rataan } \\
\hline & A0 & A1 & $\mathrm{A} 2$ & \\
\hline & (Kontrol) & (Asam Salisilat) & (Asam Askorbat) & \\
\hline \multicolumn{5}{|c|}{ 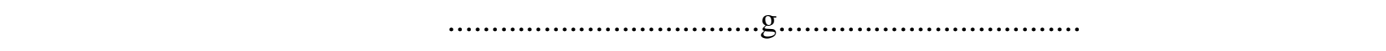 } \\
\hline K1 (80) & 1.35 & 1.43 & 1.38 & 1.39 \\
\hline K2 (60) & 1.43 & 1.15 & 1.35 & 1.31 \\
\hline $\mathrm{K} 3(40)$ & 1.32 & 1.20 & 1.38 & 1.30 \\
\hline Rataan & 1.37 & 1.26 & 1.37 & \\
\hline
\end{tabular}




\section{Rasio Tajuk Akar}

Rataan rasio akar tajuk pada perlakuan cekaman kekeringan dan pemberian antioksidan dapat dilihat pada Tabel 7.

Tabel 7.Rasio tajuk akar kedelai dengan perlakuan pemberian antioksidan dan cekaman kekeringan.

\begin{tabular}{|c|c|c|c|c|}
\hline \multirow{2}{*}{$\begin{array}{c}\text { Cekaman Kekeringan } \\
(\% \mathrm{KL})\end{array}$} & \multicolumn{3}{|c|}{ Antioksidan } & \multirow[b]{2}{*}{ Rataan } \\
\hline & $\begin{array}{c}\mathrm{A} 0 \\
\text { (Kontrol) }\end{array}$ & $\begin{array}{c}\mathrm{A} 1 \\
\text { (Asam.Salisilat) }\end{array}$ & $\begin{array}{c}\text { A2 } \\
\text { (Asam.Askorbat) }\end{array}$ & \\
\hline & \multicolumn{4}{|c|}{ 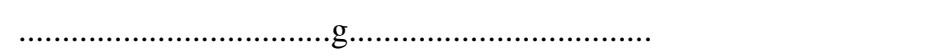 } \\
\hline K1 (80) & 13.19 & 11.09 & 13.28 & 12.52 \\
\hline K2 (60) & 14.66 & 12.62 & 9.40 & 12.23 \\
\hline K3 (40) & 11.39 & 14.12 & 10.24 & 11.92 \\
\hline Rataan & 13.08 & 12.61 & 10.98 & \\
\hline
\end{tabular}

\section{Jumlah Cabang Produktif}

Rataan jumlah cabang produktif pada perlakuan cekaman kekeringan pemberian antioksidan dapat dilihat pada Tabel 8.

Tabel 8.Jumlah cabang produktif kedelai dengan perlakuan pemberian antioksidan dan cekaman kekeringan.

\begin{tabular}{|c|c|c|c|c|}
\hline \multirow{2}{*}{$\begin{array}{c}\text { Cekaman Kekeringan } \\
(\% \mathrm{KL})\end{array}$} & \multicolumn{3}{|c|}{ Antioksidan } & \multirow[b]{2}{*}{ Rataan } \\
\hline & $\begin{array}{c}\text { A0 } \\
\text { (Kontrol) } \\
\end{array}$ & $\begin{array}{c}\text { A1 } \\
\text { (Asam.Salisilat) } \\
\end{array}$ & $\begin{array}{c}\text { A2 } \\
\text { (Asam.Askorbat) }\end{array}$ & \\
\hline & & ......cabang... & ................. & \\
\hline K1 (80) & 3.08 & 2.92 & 2.75 & 2.92 \\
\hline K2 (60) & 2.75 & 2.67 & 2.58 & 2.67 \\
\hline K3 (40) & 2.33 & 2.42 & 2.92 & 2.56 \\
\hline Rataan & 2.72 & 2.67 & 2.75 & \\
\hline
\end{tabular}

\section{Jumlah Polong Berisi Pertanaman}

Rataan jumlah polong berisi per tanaman pada perlakuan cekaman kekeringan pemberian antioksidan dapat dilihat pada Tabel 9.

Tabel 9.Jumlah polong berisi per tanaman kedelai dengan perlakuan pemberian antioksidan dan cekaman kekeringan.

\begin{tabular}{|c|c|c|c|c|}
\hline \multirow{2}{*}{$\begin{array}{c}\text { Cekaman Kekeringan } \\
(\% \mathrm{KL})\end{array}$} & & Antioksidan & & \multirow[b]{2}{*}{ Rataan } \\
\hline & $\begin{array}{c}\text { A0 } \\
\text { (Kontrol) }\end{array}$ & $\begin{array}{c}\text { A1 } \\
\text { (Asam.Salisilat) }\end{array}$ & $\begin{array}{c}\text { A2 } \\
\text { (Asam.Askorbat) }\end{array}$ & \\
\hline K1 (80) & 41.22 & 40.00 & 47.11 & $42.78 \mathrm{a}$ \\
\hline K2 (60) & 38.22 & 34.33 & 41.00 & $37.85 b$ \\
\hline K3 (40) & 33.00 & 39.89 & 38.44 & $37.11 \mathrm{~b}$ \\
\hline Rataan & $37.48 b$ & $38.07 \mathrm{~b}$ & $42.19 \mathrm{a}$ & \\
\hline
\end{tabular}

Keterangan: Angka-angka yang diikuti huruf yang sama menunjukkan berbeda tidak nyata menurut Uji Duncan Multiple Tect pada taraf $\alpha=5 \%$ 


\section{Jumlah Polong Hampa Pertanaman}

Rataan jumlah polong hampa per tanaman pada perlakuan cekaman kekeringan dan pemberian antioksidan dapat dilihat pada Tabel 10.

Tabel 10. Jumlah polong hampa per tanaman kedelai dengan perlakuan pemberian antioksidan dan cekaman kekeringan.

\begin{tabular}{ccccc}
\hline \multirow{2}{*}{$\begin{array}{c}\text { Cekaman Kekeringan } \\
(\% \text { KL) }\end{array}$} & A0 & A1 & Antioksidan & Rataan \\
\cline { 2 - 4 } & $($ Kontrol) & (Asam Salisilat) & (Asam Askorbat) & \\
\hline K1 (80) & 13.33 & 12.33 & 13.67 & 13.11 \\
K2 (60) & 14.33 & 11.33 & 12.33 & 12.67 \\
K3 (40) & 13.67 & 13.33 & 10.00 & 12.33 \\
\hline Rataan & 13.78 & 12.33 & 12.00 & \\
\hline
\end{tabular}

\section{Bobot Kering Biji Per Tanaman}

Rataan bobot kering biji pertanaman pada perlakuan cekaman kekeringan dan pemberian antioksidan dapat dilihat pada Tabel 11.

Tabel 11. Bobot kering biji per tanaman dengan perlakuan pemberian antioksidan dan cekaman kekeringan.

\begin{tabular}{|c|c|c|c|c|}
\hline Cekaman & \multicolumn{3}{|c|}{ Antioksidan } & \multirow[t]{3}{*}{ Rataan } \\
\hline Kekeringan & A0 & A1 & $\mathrm{A} 2$ & \\
\hline$(\% \mathrm{KL})$ & (Kontrol) & (Asam Salisilat) & (Asam Askorbat) & \\
\hline \multicolumn{5}{|c|}{ 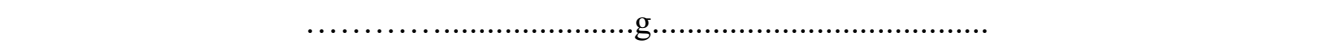 } \\
\hline K1 (80) & $7.43 \mathrm{a}$ & $5.86 \mathrm{f}$ & $6.38 \mathrm{~cd}$ & $6.56 \mathrm{a}$ \\
\hline K2 (60) & $6.26 \mathrm{de}$ & $6.61 b c$ & $6.28 \mathrm{de}$ & $6.38 \mathrm{ab}$ \\
\hline K3 (40) & $5.93 f$ & $6.69 b$ & $6.02 \mathrm{ef}$ & $6.21 b$ \\
\hline Rataan & $6.54 \mathrm{a}$ & $6.39 \mathrm{ab}$ & $6.23 b$ & \\
\hline
\end{tabular}

\section{Bobot Kering 100 Biji}

Rataan bobot kering 100 biji pada perlakuan cekaman kekeringan dan pemberian antioksidan dapat dilihat pada Tabel 12.

Tabel 12.Bobot kering 100 biji dengan perlakuan pemberian antioksidan dan cekaman kekeringan

\begin{tabular}{|c|c|c|c|c|}
\hline \multirow{3}{*}{$\begin{array}{c}\text { Cekaman Kekeringan } \\
(\% \mathrm{KL})\end{array}$} & \multicolumn{3}{|c|}{ Antioksidan } & \multirow{3}{*}{ Rataan } \\
\hline & A0 & A1 & $\mathrm{A} 2$ & \\
\hline & (Kontrol) & (Asam Salisilat) & (Asam Askorbat) & \\
\hline & \multicolumn{4}{|c|}{ - } \\
\hline K1 (80) & $9.05 b$ & $8.95 b c$ & $8.78 \mathrm{~cd}$ & $8.92 \mathrm{a}$ \\
\hline K2 (60) & $9.39 \mathrm{a}$ & $8.39 \mathrm{e}$ & $8.93 b c$ & $8.90 \mathrm{ab}$ \\
\hline K3 (40) & $8.60 \mathrm{~d}$ & $8.74 \mathrm{~cd}$ & $8.26 \mathrm{e}$ & $8.54 b$ \\
\hline Rataan & $9.01 \mathrm{a}$ & $8.69 \mathrm{ab}$ & $8.66 b$ & \\
\hline
\end{tabular}

Keterangan: Angka-angka yang diikuti huruf yang sama menunjukkan berbeds tidak nyata menurut Uji Duncan Multiple Tect pada taraf $\alpha=5 \%$. 
Berdasarkan hasil pengamatan dan sidik ragam diketahui bahwa perlakuan cekaman kekeringan berpengaruh nyata terhadap total luas daun,jumlah polong berisi per tanaman, bobot kering biji per tanaman dan bobot kering 100 biji.

Perlakuan pemberian cekaman kekeringan berpengaruh nyata terhadap total luas daun. Total luas daun tertinggi pada $80 \% \mathrm{KL}$ (K1) yaitu $641.59 \mathrm{~cm} 2$ dan terendah diperoleh pada perlakuan $40 \%$ KL (K3) yaitu $477.11 \mathrm{~cm} 2$. Peningkatan cekaman kekeringan $(80 \%-40 \%$ KL) cenderung menurunkan total luas daun. Hal ini disebabkan karena kebutuhan air tidak dipenuhi maka pertumbuhan tanaman akan terhambat, cekaman kekeringan mempengaruhi pertumbuhan dan metabolisme tanaman.

Berdasarkan hasil pengamatan dan sidik ragam diketahui bahwa pemberian antioksidan berpengaruh nyata terhadap klorofil a, klorofil $b$, jumlah polong berisi pertanaman, bobot kering biji pertanaman dan bobot kering 100 biji..

Perlakuan pemberian antioksidan berpengaruh nyata terhadap klorofil daun a, klorofil daun b, jumlah polong berisi per tanaman, bobot kering biji per tanaman dan bobot kering 100 biji. Klorofil daun a tertinggi yaitu asam salisilat (A1) yaitu $1.94 \mathrm{mg} / \mathrm{l}$, rataan terendah pada tanpa pemberian antioksidan (A0) yakni $1.76 \mathrm{mg} / \mathrm{l}$. Klorofil daun b tertinggi yaitu bahwa tanpa perlakuan (A0) menghasilkan rataan tertinggi yakni $2.41 \mathrm{mg} / \mathrm{l}$, dan rataan terendah pada pemberian antioksidan asam salisilat(A1) yakni $1.69 \mathrm{mg} / \mathrm{l}$. Total klorofil daun diketahui bahwa tanpa perlakuan (A0) menghasilkan rataan tertinggi yakni $4.15 \mathrm{mg} / \mathrm{l}$, dan rataan terendah pada pemberian antioksidan asam salisilat (A1) yakni $3.50 \mathrm{mg} / \mathrm{l}$.

Berdasarkan hasil penelitian dan sidik ragam diketaui bahwa Interaksi antara pengaruh cekaman kekeringan dan pemberian antioksidan berpengaruh nyata terhadap peubah amatan, bobot kering biji pertanaman, dan bobot 100 biji.

Pada interaksi antara pengaruh cekaman kekeringan dan pemberian antioksidanberpengaruh nyata terhadap bobot kering biji per tanaman. Bobot kering biji per tanaman yang tertinggi diperoleh pada K1A0 yaitu $7.43 \mathrm{~g}$ dan terendah K1A1 yaitu $5.86 \mathrm{~g}$.

\section{Simpulan}

Peningkata perlakuan cekaman kekeringan dari $80 \%$ KL - 40\% KL dapat menurunkan terhadap total luas daun, jumlah polong berisi pertanaman, bobot kering biji pertanaman, dan bobot 100 biji kering. Perlakuan pemberian antioksidan asam askorbat meningkatkan jumlah polong berisi per tanaman dan menurunkan jumlah polong hampa per tanamanserta perlakuan tanpa pemberian antioksidan meningkatkantotal klorofil, jumlah polong hampa pertanaman, bobot kering biji pertanaman dan bobot kering 100 biji per tanaman tetapi menurunkan jumlah polong berisi. Pemberian antioksidan asam salisilat dengan semakin meningkatnya cekaman kekeringan nyata meningkatkan bobot kering biji per tanaman, sedangkan pada perlakuan tanpa antioksidan dan asam salisilat terjadi penurunan bobot kering biji pertanaman dengan semakin meningkatnya cekaman kekeringan (80\% KL$40 \% \mathrm{KL}$ ). 


\section{Referensi}

Ardiansyah, M. 2013. Respons Pertumbuhan dan Produksi Kedelai Hasil Seleksi Terhadap Pemberian Asam Askorbat dan Inokulasi Fungi Mikoriza Arbuskular di Tanah Salin. Universitas Sumatera Utara. Medan.

Fentami, N. A. 2012. Uji Aktivitas Antioksidan Total pada Bahan Nabati Yang Mengandung Vitamin E. Skripsi. Fakultas Pertanian. Universitas Andalas. Padang.

Julyasih, K. S. M., Wirawan, I. G. P., Harijani, W. S. dan W. Widajati. 2009. Aktivitas Antioksidan Beberapa Jenis Rumput Laut (Seaweeds) Komersial di Bali.Fakultas Pertanian UPN "Veteran" Jawa Timur. Surabaya.

Li, T., Y. Hu, X. Du, H. Tang, C. Shen, J. Wu. 2014. Salicylic Acid Alleviates the Adverse Effects of Salt Stress in Torreya grandis cv. Merrillii Seedlings by Activating Photosynthesis and Enhancing Antioxidant Systems. Plos One 9 (10).

Notohadinegoro, T. 2000. Diagnostik Fisik Kimia dan Hayati Kerusakan Lahan.Makalah pada Seminar Pengusutan Kriteria Kerusakan Tanah/Lahan.Asmendep I Lingkungan Hidup/ Bapedal, 1-3 Juli 1999. Yogyakarta.

Ramadhani, E. 2009.Respons Pertumbuhan dan Produksi Kedelai (Glycine max (L.)Merril.)terhadap Perbedaan Waktu Tanam dan Inokulasi Rhizobium. Universitas Sumatera Utara. Medan.

Sulastri, S. 2014. Bab I. Dikutip dari http://unsri.ac.id.Diakses pada tanggal 24 Maret 2016. 